\title{
Encounters with Sexuality: The Management of Inappropriate Body Behaviour in Late-Nineteenth-Century British Columbia Schools ${ }^{1}$
}

\author{
Jean Barman
}

Of all the issues that students, parents, teachers, and schools encounter, few are so difficult to manage as sexuality. We persist in believing that the body does not belong in the classroom except as an object of study or improvement. Inappropriate body behaviour with a sexual edge intimidates us, so much so that accounts tend to be oblique or non-existent. Their scarcity makes particularly valuable a set of records that survive from British Columbia in the late nineteenth century. Even though public education was becoming centralized, a general unwillingness to face up to issues of sexuality caused almost all of the thirty allegations that were located in the Superintendent of Education's correspondence to be resolved at the local level. The most frequent tactic was parental boycott of the school. The allegations divide between those against teachers and those against students. Regardless of who was implicated, the teacher was almost always caught in the middle and ended up resigning.

De tous les enjeux auxquels font face les élèves, les parents, les enseignants et les écoles, peu sont aussi difficiles à gérer que ceux touchant la sexualité. On continue de croire que le corps n'appartient pas à la salle de classe sauf comme objet d'étude ou susceptible d'être amélioré. Un comportement corporel inapproprié à caractère sexuel gêne à un point tel qu'il est consigné autrement ou pas du tout. Leur rareté rend donc particulièrement précieux un ensemble de registres de la fin du $\mathrm{XIX}^{\mathrm{e}}$ siècle en provenance de la Colombie-Britannique. Même si l'instruction publique y était en voie de centralisation, le peu d'empressement des autorités scolaires à régler les questions de sexualité a fait en sorte que presque toute la trentaine d'allégations qui furent adressées au surintendant de l'instruction publique furent résolues au niveau local. La tactique la plus fréquente était le boycottage des écoles par les parents. Les accusations sont portées contre les maitres et contre les élèves. Ceci étant dit, peu importe qui était impliqué, le maître était presque toujours pris au cœur du litige et finissait par démissionner.

1 I am grateful to the Social Sciences and Humanities Research Council of Canada for supporting the research on which this essay draws and to the various students who assisted in that research. Dana Whyte drew my attention to these incidents, and then searched them out, when she was going through the microfilm for me for another purpose. Special thanks to Patricia Roy, J. Donald Wilson, Mona Gleason, and three anonymous assessors for their perceptive comments on earlier versions of this essay.

(CHistorical Studies in Education / Revue d'histoire de l'éducation 16, 1 (2004): 85-114 
Of all the issues that students, parents, teachers, and schools encounter, few are so difficult to manage as sexuality. We persist in believing that the body does not belong in the classroom except as an object of study or improvement. Body betterment has long been acceptable, as with early-twentieth-century initiatives to monitor student health and introduce sex education, and more recent efforts to feed hungry bodies attending inner city schools. ${ }^{2}$ It is when the body takes on a life of its own in order to pleasure itself that we become agitated. Inappropriate body behaviour with a sexual edge intimidates us, so much so that accounts tend to be oblique or nonexistent. Their scarcity makes particularly valuable a set of records that survive from British Columbia in the late-nineteenth century. The intervening century may have changed contexts, but the elements of ambivalence and difficulties of resolution are hauntingly familiar. ${ }^{3}$

A systematic reading of the incoming and outgoing correspondence of the Superintendent of Education, which survives from 1872 to 1897 , turned up thirty allegations of inappropriate body behaviour by teachers or students. ${ }^{4}$ These are not, it must be

2 Mona Gleason, "Disciplining the Student Body: Schooling and the Construction of Canadian Children's Bodies, 1930-1960,” History of Education Quarterly 41, 2 (2001): 189-215; Christabelle Sethna, "Men, Sex, and Education: The Ontario Women's Temperance Union and Children's Sex Education, Ontario, 1900-20," Ontario History 88, 3 (1996): 185-206; Noel Herron, Every Kid Counts: Inner City Schools in Vancouver (Vancouver: Vancouver Elementary Teachers Association, 2001); also Jeffrey P. Moran, Teaching Sex: The Shaping of Adolescence in the $20^{\text {th }}$ Century (Cambridge: Harvard University Press, 2000).

3 Current interest derives in good part from Michel Foucault, especially the first volume of his The History of Sexuality (New York: Pantheon, 1978). Foucault sought to move thinking away from sexed persons and their desires toward unmarked bodies and their pleasures. His writing has not transformed scholarship about children in schools to the same extent it has the field we now know as queer theory. Among recent writing attempting to open up discussion in several directions are Sue Middleton, Disciplining Sexuality: Foucault, Life Histories, and Education (New York: Teachers College Press, 1998); Debbie Epstein and Richard Johnson, Schooling Sexualities (Buckingham, UK: Open University Press, 1998); Debbie Epstein, "Boys' Own Stories: Masculinities and Sexualities in Schools," Gender and Education 9, 1 (1997): 105-15; Debbie Epstein, Mary Kehily, Maírtin Mac an Ghaill, and Peter Redman, "Boys and Girls Come Out to Play: Making Masculinities and Femininities in School Playgrounds," Men and Masculinities 4, 2 (October 2001): 158-72; Mary Kehily, "Bodies in School: Young Men, Embodiment, and Heterosexual Masculinities," Men and Masculinities 4, 2 (October 2001): 173-85.

4 British Columbia Archives (BCA), British Columbia Superintendent of Education (BCSE), Inward Correspondence (IC), GR1445, reels B2017-B2030, and Outward Correspondence (OC), GR450, reels B8503-B8520. The correspondence is incomplete for the earlier years. To compensate, the first Superintendent of Education's travel diary was also examined, and one incident taken from it. John Jessup, "School Inspector's Diary 1872-77," manuscript in BCA, C/C/30.12M/2. Many more cases could certainly be located in the superintendent's correspondence, the effective prohibitions respecting 
emphasized, the entirety of incidents, but rather only those warranting correspondence with the superintendent. ${ }^{5}$ The allegations are also limited by geography. None came from the province's four urban centres of Victoria, Nanaimo, New Westminster, and, from 1886, Vancouver. These were the only locations visited regularly by authorities, meaning that consultations on contentious issues were likely verbal. ${ }^{6}$

Not all of the thirty allegations of inappropriate body behaviour were sexual in their impetus. Rather, they all acquired a sexual edge. Part of the reason they did so persists today in our fear of bodies out of control. Another part of the reason lies in the deep ambivalence toward the body that characterized the late-nineteenth century. ${ }^{7}$ Across much of British Columbia, frontier conditions made the sex act, for reproduction but also for pleasure, a recognized part of daily life from a young age. ${ }^{8}$ As Sharon Ullman describes for the United States, this everyday reality stood in sharp contrast to "middle-class arbiters of public and private behavior, who attempted to police sexuality through moral authority" and whose "opinions and ideology permeate the documentary evidence." Such persons saw themselves as setting standards for behaviour, in British Columbia as elsewhere

sexuality being such that the language was often very coded. Bruce Curtis appears to have located just over fifty "complaints of sexual contact between (male) teachers and (female) students" in Ontario between 1850 and 1907 which came to the attention of "local administrative agencies" after "community regulation failed." He also struggled with "the vague and ambiguous language used to describe sexual complaints against teachers.” See Curtis, “'Illicit' Sexuality and Public Education in Ontario, 1840-1907,” Historical Studies in Education 1, 1 (Spring 1989): 79.

5 Even so, corroborating sources of information are almost always silent on the specifics, much as occurs in the present day. In just two cases did an incident make it into the annual printed report of the Department of Education, whose concern was to uplift rather than highlight shortcomings. The exceptions were Cache Creek (\#5, Table 1) and Salt Spring (\#13). Department of Education, Annual Report, 1876-77, 63-67; and 188182 , 209. The annual reports do list teaching staffs, making it possible to trace whether teachers in a school where an allegation occurred stayed, moved on to another job, or left teaching altogether.

6 Clearly misbehaviour also occurred in urban centres, as indicated by the six-month suspension of the certificate of the first assistant in the Victoria high school in February 1895 "until the charge of gross misconduct preferred against him has been finally acted upon by the Council.” Decree of 4 February 1895, Council of Public Instruction, “Decrees,” p. 79, in BCA, GR138, vol. 1.

7 For a general introductory discussion of nineteenth-century attitudes, see Gail Hawkes, A Sociology of Sex and Sexuality (Buckingham and Philadelphia: Open University Press, 1996).

8 For general background, see Jean Barman, The West beyond the West: A History of British Columbia, rev. ed. (Vancouver: University of Toronto Press, 1996).

9 Sharon R. Ullman, Sex Seen: The Emergence of Modern Sexuality in America (Berkeley: University of California Press, 1997), 2. 
across North America. The sex act might be necessary for procreation, but that did not make either it or sexuality a proper topic for open discussion, except to be condemned. The thinking was gendered, in line with the patriarchal character of the times. Men were acknowledged to possess sexual desire, which was to be satisfied within the married state. Women did not. So as not to arouse their men folk, women were to behave modestly, preferably under male supervision, and to think pure thoughts. Persons in poor economic circumstances or of darker skin tones were considered more likely to behave improperly. The tendency was inherited, ran the thinking. Their bodies were more highly sexed. As the century waned, more and more aspects of body behaviour acquired a sexual edge and thereby, in the guise of "moral purity," were in need of regulation and reform. ${ }^{10}$ Sexualization of body behaviour was extremely convenient for a variety of reasons.

During these same years, public education was becoming increasingly centralized, but the shift went only so far. ${ }^{11}$ The attitudes of persons in charge prevented schools, as described for Ontario by Bruce Curtis, from dealing with improper body behaviour. ${ }^{12}$ Shortly after British Columbia became a Canadian province in 1871, responsibility for the "order and discipline" of schools was invested

10 These points are explicated in Leonore Davidoff and Catherine Hall, Family Fortunes: Men and women of the English middle class, 1780-1850 (London: Hutchinson, 1987); Alan Hunt, Governing Morals: A Social History of Moral Regulation (Cambridge: Cambridge University Press, 1999); Helen Lefkowitz Horowitz, Rereading Sex: Battles over Sexual Knowledge and Suppression in Nineteenth-Century America (New York: Alfred A. Knopf, 2002); Mary E. Odem, Delinquent Daughters: Protecting and Policing Adolescent Female Sexuality in the United States, 1885-1920 (Chapel Hill: University of North Carolina Press, 1995); Mariana Valverde, The Age of Light, Soap, and Water: Moral Reform in English Canada, 1885-1925 (Toronto: McClelland and Stewart, 1991); Carolyn Strange and Tina Loo, Making Good: Law and Moral Regulation in Canada, 1867-1939 (Toronto: University of Toronto Press, 1997).

11 The essays in Allan Greer and Ian Radforth, eds., Colonial Leviathan: State Formation in Mid-Nineteenth-Century Canada (Toronto: University of Toronto Press, 1992), describe the shift from a variety of perspectives. Also useful is Paul Axelrod, The Promise of Schooling: Education in Canada, 1800-1914 (Toronto: University of Toronto Press, 1997).

12 Researching “Ontario through the last half of the nineteenth century,” Bruce Curtis determined that "in official documents and discussions, in the literature of educational reform and educational theory, a generalized silence about sexuality prevailed." See Curtis, “'Illicit' Sexuality,” 76. Curtis describes as "purposive vagueness" the tendency of the education office in Canada West, 1836-71, to respond to queries concerning discipline "simply by citing the general provisions of the School Acts or of school regulations." Much as occurred in British Columbia, "comment on the merits of particular cases was usually avoided.” Bruce Curtis, Building the Educational State: Canada West, 1836-1871 (London, ON: The Althouse Press and Falmer Press, 1988), 341. 
in a Superintendent of Education. ${ }^{13}$ Among other powers, he had authority to charge any person who "interrupts or disquiets any Public School by rude or indecent behavior." 14 The routine administration of schools fell on three elected trustees, who were very often parents of students. From 1873 local trustees had the right to dismiss, as well as to hire, teachers. They could do so from 1879 "upon giving at least thirty days' notice," from 1888 immediately, for "gross misconduct." 15 Teachers, who until the turn of the century qualified by passing an examination, were charged to "maintain proper order and discipline" within their school. ${ }^{16}$ As for parents, they were from 1876 responsible that their children, "from the age of seven to twelve inclusive, shall attend some School, or be otherwise educated for six months in every year." 17

For all of the administrative centralization, the Superintendent of Education played a far smaller role than did direct action in encounters with sexuality. Almost all of the thirty allegations during this quarter of a century were resolved through local initiative because the state proved unable or unwilling to face up to improper body behaviour, particularly when it acquired a sexual edge. ${ }^{18}$ Localities acted in two principal ways. In just over half of the cases (16/30), parents, either individually or in groups, boycotted the school. They put their children's well-being, as they perceived it, ahead of their

13 The Public School Act (PSA), Statutes of British Columbia (SBC), 1872, s. 8 (1), but not subsequent legislation promulgated from 1879 onwards gave the Superintendent of Education responsibility "for the adjustment of disputes." The superintendent had the authority, from 1879 onwards, to enquire into "the order and discipline observed" in schools that he visited. PSA, SBC, 1879, s. 9 (6); 1888, s. 54 (3); 1891, s. 8 (3). I am very grateful to Helen Brown for sharing her copies of the school legislation with me.

14 PSA, SBC, 1872, s. 36; Consolidated PSA, SBC, 1876, s. 43; PSA, SBC, 1879, s. 42; 1888, s. 60; 1891 , s. 70.

15 Public School Amendment Act (PSAA), SBC, 1873, s. 7; PSA, SBC, 1879, s. 34; PSAA, SBC, 1888, s. 4 (2); PSA, SBC, 1888, s. 48; 1891, s. 50. Up to the disbanding of the provincial Board of Education in 1879, boards had to have its agreement to dismiss teachers. The term "gross misconduct" entered the legislation obliquely in 1888 when the proviso was added that the thirty days notice did not apply when dismissal was for that reason. PSA, SBC, 1888, s. 4 (2); PSA, SBC, 1888, s. 48; 1891, s. 50. The number of trustees required in city schools was several times adjusted upwards.

$16 \quad$ PSA, SBC, 1872, s. 33 (3); 1879, s. 35 (3); 1888, s. 54 (3); 1891, s. 60 (3).

17 PSA, SBC, 1876 , s. $38 ; 1879$, s. $37 ; 1885$, s. $45 ; 1888$, s. $56 ; 1891$, s. $66 ; 1897$, s. 79. School attendance began to become required with the 1873 amendment giving trustees the power to make bylaws "requiring the parents or guardians of children of such age, not less than seven nor more than fourteen years, ... to attend School," where one existed within three miles. PSAA, SBC, 1873, s. 2 (1), 3 (3).

18 Curtis similarly notes how "the response of the central authority [Chief Superintendent] to complaints about illicit sexual behaviour by teachers was usually to refer complainants to the local authority, or simply to discredit them." Curtis, "Illicit' Sexuality," 81. 
Encounters with Sexuality 
becoming literate. Their role as parents took precedence over the state and its injunctions. Secondly, teachers and trustees used the legislation as best they could. Teachers disciplined students and, much more importantly, trustees fired teachers. Attitudes toward sexuality were so contentious that an accusation, however unjustified, even if against a student, could cause a teacher to be dismissed or to resign out of frustration.

The thirty cases have some general characteristics. The initial allegation was most often followed by direct action. Only then, if then, was there resolution. The cases are gendered. Almost threequarters $(22 / 30)$ occurred where the teacher was a man, even though 60 per cent of the thousand teachers at work in British Columbia during this quarter-century were female. ${ }^{19}$ In other words, a male teacher was four times more likely to be involved in an allegation than was his female counterpart. Even where not directly implicated, his actions could be sexualized. In general, whereas women had their reputations tarnished, men became perceived as moral threats to children and to the community. Almost three-quarters of the cases $(22 / 30)$ involved solely persons of the palest skin tones, individuals we consider White. So far as can be determined, all of the teachers fit into that category. So did most, but not all, of the students and trustees.

\section{Allegations against Teachers}

The thirty allegations divide evenly into two groups - those against teachers and those against students. All of the allegations against teachers involved persons of the opposite sex. All but three were against men, in one case the Superintendent of Education. The three exceptions occurred during the early years of public schooling when independent working women were almost inherently suspect. At Stanley in the Cariboo (\#6, Table 1), "some people began to pass remarks" about the young single teacher continuing to board in the home of a male trustee after his wife left for a month's visit to Victoria. ${ }^{20}$ At Cache Creek public boarding school (\#7), established in the interior in 1874 for children living too far apart to attend day school, the music teacher, "by a determined manipulation of her

19 Based on teacher lists included in Department of Education, Annual Reports.

20 Josephine McDonald to John Jessup, Superintendent of Education (hereafter SE), Quesnelle, 4 May 1878. All correspondence cited below, unless otherwise noted, comes from BCA, BCSE, IC, GR1445. 
shawl and by a delicate cough, which no doubt was assumed for the occasion," managed to deceive everyone "till it was too late to prevent the evil." 21 The nature of "the evil" was not revealed. Another woman spread the story at Hope in the Fraser Valley (\#8), to quote the teacher, "that something very improper had occurred between myself and a Half-breed boy about 18 years of age." The woman did so after spying on the teacher and the landlady, where they both boarded, entertaining "a young Frenchman" by dressing him "as a woman." The mere allegation, the teacher realized, turned an innocent evening into "a secret disgraceful tale." 22 These assertions of improper body behaviour may have originated in jealousy or spite but also, it is tempting to speculate, in order to legitimize open discussion of an unattached newcomer.

Some of the dozen allegations levelled against male teachers were similarly based in gossip and innuendo, as occurred twice at Maple Bay on Vancouver Island and on Salt Spring and Mayne Islands. A local trustee lambasted the teacher at Maple Bay (\#11) for "the beating of his wife [which] has been going on now for a twelve months." 23 The talk there five years later (\#15) was of the single male teacher "keeping company with... a widow lady that resides close by." 24 One of the two Salt Spring schools (\#13) was located in an area settled by Black families from the United States during the gold rush beginning in the late 1850s. The school's two Black trustees accused the Salt Spring teacher of helping their White trustee counterpart prevent his underage daughter from running away with a Black man. ${ }^{25}$ A recent school-leaver on Mayne (\#16) alleged that the teacher had, as well as using profane language, drawn images of "girls' nakedness on the benches and on the ceiling" of the school. ${ }^{26}$

Some teachers found their use of physical discipline sexualized, as at Donald in the eastern interior and Langley Prairie in the Fraser Valley. At Donald (\#22) “complaints of the teacher's brutal whipping of pupils were very common," including his having punished one girl so firmly "as to blacken both her eyes." Initially the teacher "succeeded in arousing a general feeling of sympathy on his behalf."

21 Thomas Leduc, teacher at Cache Creek, to C.C. McKenzie, SE, Cache Creek, 16 March 1880.

22 J[ane] E. Trenaman, teacher at Hope, to C.C. McKenzie, SE, Hope, 11 Dec. 1879.

23 William Beaumont, Maple Bay trustee, to C.C. McKenzie, SE, Maple Bay, 18 Feb. 1881.

24 A.M. Miller to S.D. Pope, SE, Maple Bay, 16 Aug. 1886.

25 S[am] G. Lewis, teacher on Salt Spring Island, to C.C. McKenzie, SE, Vesuvius Landing, 12 Feb. 1882.

26 Memo by D. Wilson, 16 April 1888. 
Worried that he might be kept on, the girl's father asserted that the teacher also "had been guilty of kissing one of the older girls attending the school, a daughter of [a] Trustee..., and had been seen going home with his arm around the neck of this or other girls." At a public meeting called to consider the situation, he drew attention to a letter written a year earlier by a disgruntled former resident, with whose nineteen-year-old daughter the teacher willingly acknowledged he had "kept company," but denied "ever having had any improper relations with her." The moral reform impulse is evident from the father going on to describe how the teacher "had been in the habit of playing cards on Sunday." He "was regular in attendance at Divine Worship," but "no sooner was Service over, than the cards were again brought out." 27

The incident at Langley Prairie (\#26) points up the fear of the body out of control. According to a worried trustee, the new teacher "proved to be very quick tempered and at the least possible offense in his fits of anger punished and pounded severely over the head or anywhere the blows might fall and pounded many of them most unmercifully and in his fits of passion whatever he might have in his hands threw it onto the floor spitefully pull their hair their ears their nose and eye brows and very frequently indulged in the following ill names such as little fools...dumheads [sic] miserable beings." Anxious to cement what was initially a non-sexual complaint, the trustee tacked on, almost as an afterthought, the teacher's "more than usual attention to some of the large girls." 28

Not only teachers' actions but also those of the Superintendent of Education (\#12) could be sexualized. A man disappointed on receiving a lower than expected grade after writing the annual teachers' examination demanded that the superintendent be dismissed on the grounds of his being "not worthy of his position" for having, during the exam in Victoria, "showed me the Street where women of ill fame lived." 29 The man approached the superintendent directly with what comes across as a crude attempt at blackmail: "You took a walk with me in the City of Victoria and pointed out to me a street in which women of ill-fame resided. If it will suit you better I am

27 Unsigned report to S.D. Pope, SE, Donald, 5 Sept. 1892.

28 D. L. Stone, Secretary of Belmont Trustees, to S.D. Pope, SE, Langley Prairie, 9 April 1893.

29 Joseph Boag to T.B. Humphries, Provincial Secretary, New Westminster, 19 July 1881. 
prepared to publish the particulars under oath in the [Victoria] Colonist [newspaper]." 30

The accusations of improper body behaviour levied against teachers were not all just spiteful. Some were very serious indeed, as at South Cowichan and Lakes on Vancouver Island, Vernon in the southern interior, and Port Haney and Cheam in the Fraser Valley. A South Cowichan parent (\#1) charged the teacher with "taking indecent liberties with his adopted half-breed girl aged about 9 years." 31 At Lakes (\#10) an upset hotel owner threatened to spread reports that the teacher "had been guilty of misconduct towards the girls in school." ${ }^{\prime 2}$

A long-time teacher at Vernon (\#18) was thrice charged in a twomonth period. "One was Indecent Assault committed on or about $3^{\text {rd }}$ Sept. on one girl, the $2^{\text {nd }}$ Indecent Assault $26^{\text {th }}$ Oct., \& the third, Assault \& battery on $27^{\text {th }}$ Oct. on another girl." 33 One of the girls "complained to her mother of his indecent conduct," who then informed the trustees. They got in touch with the teacher, who the very next day "beat her with a stick" until "the blood was almost raging." The local justice of the peace issued an arrest warrant after taking a deposition from her that the teacher "put his hand under the dress... and felt her breasts, on another occasion of having felt her legs and on another of meddling with her underclothing," and from her eleven-year-old sister that he had "on one occasion pressed her breasts with his hands and on another occasion felt her legs." Reflecting the dynamics of small communities, the justice of the peace took pains to emphasize that, before taking the girls' statements, he "precluded the idea of a family feud." 34

The allegations at Port Haney (\#23) underline the difficulties of coming to grips with sexual desire. Shortly after a new teacher arrived in 1891, a trustee's child "brought the subject home that one of the pupils, a girl aged about 15 was in the habit of staying in after hours." The trustees requested that the practice be discontinued, to which the teacher responded that the girl merely stayed to take down homework. Reports continued to filter to the trustee's home of the teacher "sending girls out of school for wood and then following them out, also of his disgraceful conduct when playing with the older

Joseph Boag to C.C. McKenzie, SE, New Westminster, 27 July 1881.

13 March 1874 entry in John Jessup, "School Inspector's Diary 1872-77."

Samuel Girdlestone Lewis, teacher at Lakes, to his trustees, 10 March 1880, and left

for safekeeping with C.C. McKenzie, SE.

33 R.S. Hanna to S.D. Pope, SE, Fairhaven, Washington, 31 Jan. 1890.

34 Ward Spinks to S.D. Pope, SE, Kamloops, 13 Jan. 1890. 
girls." Still nothing was done. The other two trustees opposed the teacher's dismissal on the grounds that "he brought the children on well with their studies." The teacher continued "keeping the children at night" until a young woman swore out an affidavit "that she had been seduced by her teacher when about fourteen years and five months old, when attending school; that she had had intercourse at diferent [sic] times with him up to last March and that she was with child to him, being at present 16 years old." The girl "afterwards stated to her sister that she had seen him making improper advances towards another girl between $11 \& 12$ years of age; that there were others that she was satisfied he had intercourse with all the other larger girls." ${ }^{35}$ Perhaps influenced by events at Port Haney, complaints circulated shortly thereafter at nearby Cheam (\#24) "as to the teacher having improper conduct with some of the female pupils of his school."

\section{Allegations against Students}

An equal number of allegations were levelled against students. As with teachers, all fifteen involved persons of the opposite sex. General misbehaviour could acquire a sexual edge, so the teacher twice reported from the tiny lumbering settlement of Gastown or Granville, the future Vancouver, during the mid-1870s. In early fall (\#2) the youngest of the recalcitrant sons of a trustee "shook his nakedness before a class of little girls." 37 The next spring (\#3) a nineyear-old boy who had already been disciplined for bad language "sometimes hid in the bushes and there waited" and "interfered with the little girls" as they were walking home. ${ }^{38}$ A physician trustee at Yale in the Fraser Canyon (\#9) considered that an expelled "halfbreed boy" who came to school after hours was "acting improperly" toward pupils being kept in, an allegation the teacher attributed to her daring to consult another medical doctor than himself. ${ }^{39}$ A newly elected trustee at Silverdale in the Fraser Valley (\#27) alleged that "the boys \& girls in what they called play was [sic] having connection." 40

\footnotetext{
35 Hector Ferguson to S.D. Pope, SE, Port Haney, 28 Aug. 1892.

36 C.S. Payder, secretary of Cheam trustees, to S.D. Pope, SE, Cheam, 7 June 1893.

37 Mrs Catherine Cordiner, teacher at Granville, to John Jessup, SE, Granville, 16 Sept. 1875.

38 Mrs Catherine Cordiner, teacher at Granville, to John Jessup, SE, Granville, 18 July 1876.

39 A[delaide] Bailey, teacher at Yale, to C.C. McKenzie, SE, Yale, 31 March 1880.

40 Thomas Chester, Silverdale trustee, to S.D. Pope, SE, Silverdale, 8 June 1896.
} 
Other incidents suggest greater deliberation on the part of students. Almost from the establishment of Cache Creek boarding school, its co-education was a "great cause for complaint," in part because many of the students were of mixed race by virtue of having Aboriginal mothers. ${ }^{41}$ By the summer of 1876 (\#4) school officials were cognizant of the need "to guard still more closely against such charges of immorality as have obtained currency in the past" by keeping boys and girls wholly separate outside of classes. ${ }^{42}$ Yet the very next spring (\#5), as the teacher put it, "I made the discovery that the girls had, on at least two occasions in the dead of night, left their dormitory, passed down stairs, unfastened the door between the dining room and the passage leading to the boys' dormitory." 43

One of the most serious allegations came from the Nicola Valley in the southern interior (\#14). A mother handed the incoming male teacher a letter detailing "the conduct of the boys with my little girl." 44 She explained how "the boys had thrown her down" during the noon hour while the previous teacher was outside feeding his horse. The new teacher visited the girl's parents, who told him that the "practices had been carried on for 2 years before I came here." The teacher explained to the Superintendent of Education how "they both informed me in language that was delicate, but quite unmistakable that the children were in the habit of attempting connection with each other." Three boys aged ten to fifteen, who were cousins of the girl's father, had repeatedly held her "down on the floor \& had laid down on top of her...had pulled up her clothes [and also] squirted water up her legs with a squirt." 45 The girl's parents had, at that point, taken their daughter out of school, but were returning her now that the new teacher had arrived.

Over time, as social reform talk grew louder, teachers became increasingly perceived as accountable for children's behaviour beyond the school itself. A boy on South Gabriola Island (\#17) was accused of having "committed a vile immoral act on the road home from

41 John Jessup, SE, to Provincial Secretary, Victoria, 7 July 1876, reprinted in British Columbia Department of Education, Annual Report, 1876, 96.

42 R.M. Clemitson, Deputy SE, to John Jessup, Cache Creek, 24 October 1876, reprinted in British Columbia Department of Education, Annual Report, 1876, 99.

43 "The Cache Creek Boarding School Scandal!” Colonist, 15 April 1877.

44 Agnes Woodward to Charles J. Hamilton, enclosed in Charles J. Hamilton, teacher in the Nicola Valley, to C.C. McKenzie, SE, Nicola Valley, 22 April 1882.

45 Charles J. Hamilton, teacher in the Nicola Valley, to C.C. McKenzie, SE, Nicola Valley, 22 April 1882. 
school." ${ }^{46}$ Events at Alberni on Vancouver Island (\#19) swirled around a fifteen-year-old "Indian girl" who had eloped with an Aboriginal man but then returned home. Two of the trustees gave the girl permission to go back to school, this at a time when Aboriginal children were still part of many public school classrooms in British Columbia. Thereupon, "one of the parents objected strenuously, on the grounds of immorality." At Golden in the far east of the province (\#21), one of the trustees "happened to be in the outskirts of the town \& hearing voices proceeding from a hay shed, approached, and found the child mentioned examining, \& offering herself for examination to, another member of the School." 48 A Langley parent (\#28) complained that "my children has been attempted to be raped along the road home by the older scollars [sic] one little girl $81 / 2$ and the other $61 / 2 . " 49$

The voices of students come through vividly at Aldergrove, also in the Fraser Valley (\#20). A father reported that his six-year-old daughter had been "outraged... on the road home" from school. ${ }^{50}$ The girl described how two boys "chased me and knocked me down." She explained that "they then took off my clothes," one "held me down" while the other "bothered me." The four accused acknowledged that, "when school was out," they decided "to ride the girl" and so "knocked her down and took off her drawers." Two of the boys held her while a third "got to her," they then traded places, and all four "got to her" before "a woman went past." Three of the boys ran off whereas the fourth stayed behind to help her put her clothes back on. ${ }^{51}$

Newcomers who arrived in British Columbia following the completion of the transcontinental railroad in 1886 sometimes brought with them very definite ideas about right behaviour. Body talk with a sexual edge came to the fore on Salt Spring, at Mission in the Fraser Valley, and at nearby Hope. A newcomer trustee on Salt Spring (\#29) vigorously criticized the teacher for having during the noon hour left "the children to their own will \& pleasure" rather than "keep a supervision over them while at their play, etc." $\mathrm{He}$ considered that "when the children are left alone \& together they

\footnotetext{
46 S. Ruston, teacher at South Gabriola, to S.D. Pope, SE, South Gabriola, 7 June 1888.

47 A. Percival Proctor to S.D. Pope, SE, Alberni, 23 Sept. 1889.

48 Henry J. Sharpe and J.C. Greene, Golden trustees, to S.D. Pope, SE, Golden, 10 April 1891.

49 Mrs. H.A. Oakes to S.D. Pope, SE, Langley, 24 July 1895.

50 Arthur F. Goldsmith to S.D. Pope, SE, Aldergrove, 29 April 1893.

51 Evidence of inquiry to S.D. Pope, SE, Aldergrove, 26 May 1890.
} 
engage often in talk, which is entirely out of place for children to use." $" 52$

It is not surprising, given Protestants' leadership in social reform, that a newcomer who was "strongly Methodist" serious state of immorality existing amongst the larger children attending the Mission City School" (\#25). He described their talk: "A few days since two little girls about seven or nine years of age in one of their jargons with the bigger girls, the bigger girls told them that they would take their pants off and lay them across their nee [sic] and slap their Lasses. They replied if you did we would tell or [sic] Ma out she would come and tell the teacher. They replied we would take her pants off too and slap her Lass." 54

The male teacher at Hope (\#30) attempted to turn concern over body talk to his advantage. He deflected the gossip that he was "very badly addicted to the drinking habit \& sadly neglects the school rules in different ways" by blaming his failings, including the extensive use of physical force, on students' "gross immorality \&...obscene language" while he was out of the classroom. ${ }^{55}$ Although both sexes were involved, it was girls' graphic language ("skunk piss," "swing your didlie") and their imitation of the sexual act ("she was making a ring with one finger and thumb and running her other finger through, saying this is [a boy student's] pussy and this is mine") that he considered absolved him of blame. ${ }^{5}$

\section{Direct Action}

Irrespective of their merits, allegations of inappropriate body behaviour tended to precipitate direct action. Even as trustees and teachers might be sorting out a charge, parents very often took the initiative. In just over half (16/30) of the cases, some form of boycott occurred. Its power lay in the provincial requirement that, to stay open, schools had to enroll a minimum number of students, usually ten. Many schools were not much above that number. A decision by one or two families to keep their offspring home not only discredited the teacher, it forced the hand of the trustees.

52 T.W. Mouat, trustee, to S.D. Pope, SE, Vesuvius Bay, 13 Aug. 1895.

53 Daphne Sleigh, Go Ahead or Go Home: The Trethewey Story (Abbotsford: Vicarro Publishing, 1994), 40.

54 James Tretheway to S.D. Pope, SE, Mission City, 13 June 1893.

55 W.A. Starret, Hope trustee, to S.D. Pope, SE, Hope, 29 April 1897.

56 S.B. Campbell, teacher at Hope, to S.D. Pope, SE, Hope, 5 May 1897. 
The boycotts are important in and of themselves, but also because they highlight the inability of individuals at this point in time, whether parents, teachers, trustees, or the Superintendent of Education, to confront sexuality. No structural means existed to assist alleged victims. There is no sense whatsoever in the superintendent's correspondence that this was even a consideration. Aside from discussions concerning punishment of alleged offenders, no letters to or from the superintendent address effects, either of the acts themselves or of misplaced allegations. Parents comforted children, whether victims or perpetrators. Parents who wanted to do more sometimes saw direct action as their only recourse.

Parents who considered their children to have been victimized, either by other students or by the teacher, often instigated a boycott. Where the boycott was limited to the accused students, the effect could be beneficial to the school as a whole. The teacher at Granville (\#2) breathed a sigh of relief that the trustee's son who "shook his nakedness before a class of little girls" and who was then "lightly corrected... with a slap on the bottom with my hand" was "kept home since," for "no patience could tolerate him." "57 Most times the boycott was more general. The situation in Granville the next spring (\#3) with the boy who "interfered with the little girls" soon became so serious "that their [the girls'] parents would not finally send them to school." "58 Two decades later, the Silverdale trustee (\#27) whose wife spied children "having connection" after school explained about his own offspring that "my wife is always objecting to sending them to school and will not send them regular but says she will send them regular when I make it fit for a child to attend."59 Resistance could be intended more to make a point than to disrupt a school over the long term. After the Cache Creek dormitory incident (\#7), enrolment fell from twenty-six to just fifteen, but soon bounced back up as parents in remote areas, having made their point, acknowledged the lack of other educational options. ${ }^{60}$

Boycott was most straightforward where the teacher was the accused, as on Salt Spring and at Vernon. The Salt Spring teacher (\#13) accused of helping a White trustee prevent his daughter from

57 Mrs Catherine Cordiner, teacher at Granville, to John Jessup, SE, Granville, 16 Sept. 1875.

58 Mrs Catherine Cordiner, teacher at Granville, to John Jessup, SE, Granville, 18 July 1876.

59 Thomas Chester, Silverdale trustee, to S.D. Pope, SE, Silverdale, 8 June 1896.

60 Charles Semlin, Cache Creek trustee, to John Jessup, SE, Cache Creek, 17 March

1877; Robert Clemitson, teacher at Cache Creek, to John Jessup, SE, Cache Creek, 26 March and 8 May 1877. 
eloping with a Black man soon found himself, at a meeting called by the two Black trustees, listening to Black parent after Black parent proclaim that "any Teacher that would be guilty of such action I will not let him teach my children." As one parent put it, "he is prejudice [sic] to color and I do not think he is fit to teach my children." boycott followed. The Vernon teacher (\#19) accused of indecent assault soon found "children were kept at home, the week following four were kept at home,...this left three who were in attendance the last day I taught." ${ }^{62}$

The anxieties to do with sexuality were such that, so far as boycott was concerned, it was not necessarily the substance of the charge but simply its existence that triggered action. The young male teacher at Lakes (\#10) who came up against the irate hotelier was informed by him "that he could ruin any single man who held the position of teacher, by simply spreading reports to the effect that he had been guilty of misconduct towards the girls in school; that whether the reports were true or not, the result would be the same." To make the point, not only the hotel owner's two daughters, but also "two girls, who had been very regular in attendance up to that time, were suddenly withdrawn from the school but for two days before the visit of the Superintendent." ${ }^{63}$ No sooner had trustees at Maple Bay (\#15) cleared the teacher of improper behaviour toward the "widow lady" he was courting than his accuser, described as "a mad Methodist fanatic" who "goes around preaching and praying and making a nuisance of himself," initiated a boycott. The man began "going around the settlement trying to induce people to keep their Children at home from school and he says he would tie his up by the heels to the fence to dry before he would send them to the school." ${ }^{64}$ At Cheam (\#24) complaints about the teacher's "improper conduct" toward female students were sufficient for there to be "no girls going." A trustee explained to the superintendent how "none of the parents will allow any of their girls to go near him on account of his ungentlemanly manner he has been acting towards them." 65 However, when the Cheam trustees held a "meeting to investigate

61 Proceedings of public meeting, Central School House, Salt Spring, 4 Feb. 1883, enclosed in S[am] G. Lewis, teacher on Salt Spring Island, to C.C. McKenzie, SE, Vesuvius Landing, 12 Feb. 1882; also Henry Sampson to C.C. McKenzie, SE, Salt Spring Island, n.d..

62 R.S. Hanna to S.D. Pope, SE, Fairhaven, Washington, 31 Jan. 1890.

63 Samuel Girdlestone Lewis, teacher at Lakes, to his trustees, 10 March 1880, and left for safekeeping with C.C. McKenzie, SE.

64 A.M. Miller to S.D. Pope, SE, Maple Bay, 16 Aug. 1886.

65 H. Proctor, Cheam trustee, to S.D. Pope, SE, Cheam, 2 May 1893. 
trouble we could not get the girls to state what they had to their parents."66

As at Cheam, parental action was repeatedly used to force the hand of dithering trustees. At Maple Bay (\#11) the teacher's wife, "after having been beaten black and blue," confided her plight to a trustee in the hopes he could do something. On learning of the situation, parents began a boycott. Even though the teacher was able, as the trustee who made the matter public put it, to "bamboozle the other two trustees by laying all the blame on his poor wife," he could not so convince parents and thereby break the boycott. "There were only two (his [teacher's] own) children present... and today there were only four, two of them being his own." ${ }^{67}$ The Hope teacher (\#30) who, accused of drinking and excessive punishments, laid the blame on students was similarly boycotted. A former trustee whose son was "cruelly beaten with a stick \& carried black \& blue marks for 10 or 12 days after" declared how "he very much desired his children to have a chance to get an education but not at the risk of their lives." ${ }^{\prime 68}$ His five children were joined by a trustee's five also "being kept home for a change of teachers." Another father then declared, "I have seven Children which I cannot [sic] send to school" until the teacher was dismissed. ${ }^{70}$

Sometimes it was trustees' action rather than their refusal to act that precipitated boycott. In the Nicola Valley (\#14) the new teacher who on his arrival received the letter charging assault against a young girl "wished to administer corporal punishment, but the trustees informed or rather advised me not to do so as I would certainly be charged with assault by their father." Thereupon the teacher suspended three of the accused boys and the trustees voted to expel the fourth, who was the oldest among them. This boy then returned to school, informing the teacher that if he "attempted to put him out he was to summon him with a charge of assault." The teacher wisely permitted him to stay as a visitor while his father sought a meeting with the trustees on the grounds that "his boys were prepared to take back all they said and substitute another story" and that the girl's

66 C.S. Payder, secretary of Cheam trustees, to S.D. Pope, SE, Cheam, 7 June 1893. 67 William Beaumont, Maple Bay trustee, to C.C. McKenzie, SE, Maple Bay, 18 Feb. 1881.

68 W.A. Starret, Hope trustee, to S.D. Pope, SE, Hope, 29 April 1897.

69 W.A. Starret, Hope trustee, to S.D. Pope, SE, Hope, 18 June 1897.

70 James Corrigan, secretary of Hope trustees, to S.D. Pope, SE, Hope, 29 June 1897. 
father, his cousin, had been persuaded to withdraw the charges. ${ }^{71}$ The father put the blame directly on the new teacher for raising the matter in the first place. "My son has been going to school for about 10 years and always bore a good character and there was never any fuss in the school untill [sic] this master came and he raised the Devil." ${ }^{\text {,72 }}$ Likely to placate the father, who was a local worthy, the suspensions were lifted, whereupon boycott became the only recourse left to the school's thoroughly disgruntled parents. As the teacher sadly summed up, "on account of this affair every scholar has been taken away since the suspended boys returned," except for the boys themselves and a young male cousin. ${ }^{73}$ The Alberni teacher (\#19) found himself similarly squeezed in respect to the "Indian girl" seeking to return to school following her short-lived elopement. After the trustees gave in to parental pressure for her expulsion, another group of parents circulated a petition to have her readmitted, whereupon the first group threatened to remove their children "should she return." "74

The situation at Aldergrove (\#20), where a six-year-old girl was "outraged" by fellow students, seemed initially to have been quietly resolved. The guilty boys were "very severely punished by the teacher, and parents," but "allowed to remain at School, as long as they behaved themselves." 75 The decision ignored the interests of the young girl, whose parents kept both their children home so long as the attackers remained in the school. Stalemate ensued. The new teacher who arrived two years later discovered that "there is a good deal of trouble about some boys going to school which is reported not fit to attend public school and there is five families will not send while they attend school." The teacher considered it unfair that parents were "compelled to [keep] there [sic] children home on account of two or three boys." blew the situation wide open by charging the violated girl's father under the provision in the School Act requiring his children's attendance. Not only did the original accusation resurface, so did an account from the previous spring of "a girl [6 years old] lying down

71 Charles J. Hamilton, teacher in the Nicola Valley, to C.C. McKenzie, SE, Nicola Valley, 22 April 1882; also Henry Woodward to Emerson Woodward, Nicola, 18 March 1882. From the materials it is clear there was also an earlier affidavit.

72 Henry Woodward to C.C. McKenzie, SE, Nicola Lake, 12 March 1882.

73 Charles J. Hamilton, teacher in the Nicola Valley, to C.C. McKenzie, SE, Nicola Valley, 22 April 1882.

74 A. Percival Proctor to S.D. Pope, SE, Alberni, 23 Sept. 1889.

75 R. Shortreed, secretary of Aldergrove trustees, to S.D. Pope, SE, 12 May 1893.

76 Gilbert Lawrence to S.D. Pope, SE, Aldergrove, 28 April 1893. 
and a boy on top of her." 77 Families remained divided. Those whose children had remained in school considered that "the charges made of immoral conduct among the pupils are false and groundless being made for malicious \& slanderous purposes, and that the children should be held guiltless until proven guilty."78

The teacher at Golden (\#21) was similarly caught in the middle through no fault of her own. The two students caught in improper body behaviour on the way home were suspended by the trustees, "in the interests of public morality," until their fathers returned home to deal with them. The father of the girl considered to have been the instigator saw matters differently. As soon as he got back, he wrote the teacher a letter describing her action as "malevolent impertinence" and "demanding the right to have the child taught." On the trustees' instructions, the teacher refused to take her back. The father thereupon "went with the child to school \& threatened to sit there and keep the child there also, upon which the Teacher said she could not teach her, but she might remain as a guest, which she accordingly did." 79

In frustration the teacher turned to the Superintendent of Education, who in his response put the onus back on the locality. "For gross misconduct, the teacher may suspend a pupil for a specified period, and when the example of any pupil is very hurtful, the teacher, with the approval of the trustees, can expel the pupil." 80 By this time other parents had acted. "One child has been kept away from school for about two months,...\& others would sooner pay their fine [for their offspring's non-attendance] ten times over than that the pernicious example of this youngster should exercise such an evil influence over their children, or would render them, when old enough, entitled to be classed with street-walkers \& herd with the lowest of the low." Just as had the teacher to no avail, the trustees threw themselves on the mercy of the superintendent. "We must either close the school altogether, or the child...must be expelled or criminally prosecuted \& sent to a reformatory." The trustees pointed out how the situation "places a kind of premium on vice for the benefit and example of the other scholars." So far as the trustees were aware, "in the school act there is no mention of it being a reasonable excuse for a father to keep his children from school on

77 Arthur F. Goldsmith to S.D. Pope, SE, Aldergrove, 29 April 1893.

78 Petition from Shortreed residents to S.D. Pope, SE, Shortreed, 11 May 1893.

79 Henry J. Sharpe and J.C. Greene, Golden trustees, to S.D. Pope, SE, Golden, 10 April 1891.

80 S.D. Pope, SE, to M.E. Halliday, Victoria, 13 April 1891. 
account of fear of contamination." 81 Nothing ensued, despite yet another request for outside assistance. The state in the person of the Superintendent of Education was unwilling, or unable, to rectify the situation.

\section{Resolution}

A satisfactory resolution to allegations of inappropriate body behaviour was repeatedly hindered by the state's inability to face up to issues of sexuality to the same degree other aspects of the education system were being centralized. The legislation on the books might have sufficed, had Superintendents of Education been willing to act. Alberni (\#19), where the "Indian girl" eloped, was one of the few exceptions where the superintendent intervened directly between opposing groups of parents. "From the facts of the case as stated, I certainly think it advisable to refuse the girl re-admission. Her presence could not but cause talk among the children that might lead to evil consequence. It is certainly the duty of both trustees and teacher to do everything in their favor to keep the moral atmosphere of the school-room pure." 83

Otherwise, formal resolution fell on the locality, where the options were few. Sometimes nothing happened. The Silverdale trustee's wife (\#27) who caught two children "having connection" in a shed was told, on reporting the incident to another trustee, that "it was boys and girls play...going home from school." ${ }^{\prime 84}$ On the other hand, the Golden trustees (\#21) readily expelled a girl for "immorality" outside of school. New arrivals made the difference. "In cases where the children have come from England, carefully raised under their mother's care, we can see in a few months such a deterioration in behavior \& even character as would appear almost incredible to an outsider." ${ }^{\prime 5}$ In the Nicola Valley (\#14) trustees voted that the oldest of the four boys accused of assault be "expelled from the school under Section 7, Subsection 14.15 of the Regulations of

81 Henry J. Sharpe and J.C. Greene, Golden trustees, to S.D. Pope, SE, Golden, 10 April 1891.

82 PSA, SBC, 1879, s. 9 (6); 1888, s. 54 (3); 1891, s. 8 (3). See note 13.

83 S.D. Pope, SE, to G.A. Huff, Secretary of Alberni trustees, Victoria, 16 Sept. 1889.

84 Thomas Chester, Silverdale trustee, to S.D. Pope, SE, Silverdale, 8 June 1896.

85 Henry J. Sharpe and J.C. Greene, Golden trustees, to S.D. Pope, SE, Golden, 10 April 1891. 
Schools in B.C. because he was the leader in these things." 86 Likely because the action was extreme, the trustees specified their reasons with some precision. "The nature of the offense is one of gross immorality and is such as to compel the trustees to resort to this severe measure, as a means toward preventing any recurrence of a like nature, as well as a warning to the younger children, several of whom I regret to add have been equally guilty though evidently led on by the example of their senior." 87

The decision to discipline or expel students did not necessarily equate with resolution. Just as occurred with boycotts, it could be the teacher who bore the consequences, as at Granville, Cache Creek, and South Gabriola. The Granville trustees (\#3) decided in the case of the boy who "interfered with little girls" on the way home that "for the benefit of the School it was thought necessary to expell [sic] him." ${ }^{88}$ The father countered that, rather than his son being at fault, "the lady who teaches school should find some way to stop the other children from annoying him." ${ }^{\prime 89}$ After the girls at Cache Creek (\#5) found their way into the boys' dormitory, it was inordinately easy to blame the staff for being, as the main trustee put it, "so taken up with themselves or each other that they have allowed things to come to a pretty pass." In his view, "they seem to have been sleeping all winter serenely oblivious to the most scandalous conduct on the part of some of the larger pupils." "The head teacher hastened to protect himself by meting out punishment "on the guilty parties" and requesting the trustees to have "the ringleaders expelled." ensued, when the superintendent visited the school later in the spring, he was informed that "all the offending girls with one exception were still at the school." "92 The South Gabriola teacher (\#17) whose student "committed a vile immoral act on the road home from school" soon had the parents at his door, calling the teacher "interesting names" like liar and saying that their son was an angel. ${ }^{33}$

86 Charles J. Hamilton, teacher in the Nicola Valley, to C.C. McKenzie, SE, Nicola Valley, 22 April 1882.

87 M. Armytage, secretary of board of trustees, to Henry Woodward, Nicola Lake, 7 Feb. 1882.

88 Mrs Catherine Cordiner, teacher at Granville, to John Jessup, SE, Granville, 18 July 1876.

89 L. Gold to John Jessup, SE, undated.

90 Charles Semlin, Cache Creek trustee, to John Jessup, SE, Cache Creek, 17 March 1877.

91 “The Cache Creek Boarding School Scandal!” Colonist, 15 April 1877.

9222 May 1874 entry in John Jessup, “School Inspector’s Diary 1872-77.”

93 S. Ruston, teacher at South Gabriola, to S.D. Pope, SE, South Gabriola, 7 June 1888. 
Resolution was sometimes confounded by race. A resort to skin tones is not unexpected, given the widespread tendency to attribute sexual desire to supposedly "inferior" types. The equation was most visible in terms of students identified as Aboriginal or part-Aboriginal by descent. ${ }^{94}$ Education of status Aboriginal children was legally the responsibility of the federal government, which gave an additional basis for resolution not necessarily in students' best interests. Their presence in some local classrooms related primarily to the need to keep up numbers. The Superintendent of Education resorted to this administrative consideration in responding to the teacher at Alberni (\#19) caught in the dilemma over readmitting the Aboriginal girl. "Permit me to add that as Indian children are wards of the Dominion Government, the interests of the other children should be considered first." 95

Children of mixed Aboriginal and non-Aboriginal descent were also suspect, needing, as the first Superintendent of Education put it, to be "under constant surveillance as to their conduct and demeanor." 66 After the Cache Creek incident(\#5), observer after observer waxed indignant that, to quote one of them, "children so young should show themselves capable of such depravity...a revelation of youthful vice for which I was not prepared. It may seem hard to say it, but I think it goes for all experienced opinions, that half-breeds are more immoral than the natives, and that the efforts made to educate them are almost a waste of energy." 97 The teacher at Hope (\#30) similarly put any failings he himself might have on the bad language of his pupils, many of whom were of mixed Aboriginal and non-Aboriginal descent. "When a child becomes so polluted by home influences as to be a menace to the moral status of the school I consider some action on my part necessary.",98

The race card could be turned on its head. The father at Granville (\#3) sought to shift the blame for his son's behaviour to the teacher on the grounds the family was Jewish, "being a Hebrew which some one has told the other children, some of them use bad language often used by grown up people against a race people are

94 See Jean Barman, "Schooled for Inequality: The Education of British Columbia Aboriginal Children”; and Jean Barman, "Families vs. Schools: Children of Aboriginal Descent in British Columbia Classrooms of the Late Nineteenth Century," both in Jean Barman and Mona Gleason, eds., Children, Teachers and Schools in the History of British Columbia, $2^{\text {nd }}$ ed. (Calgary: Detselig, 2003).

95 S.D. Pope, SE, to G.A. Huff, secretary of Alberni trustees, Victoria, 16 Sept. 1889.

96 British Columbia Department of Education, Annual Report, 1874, 10.

97 George Murray to John Jessup, SE, Cache Creek, 21 March 1877.

98 S.B. Campbell, teacher at Hope, to S.D. Pope, SE, Hope, 5 May 1897. 
prejudiced against" and "to those who annoy him he returns bad language." In the father's view, "in a school where all races are mixed it requires strict supervision to prevent bad conduct and language." He was not above a little prejudice of his own, observing that "some of the boys are too old to be mixed with mere children: especially as the oldest are of Indian race from which very little good can be expected." 99

The Salt Spring teacher (\#13) alleged to have helped a White trustee prevent his daughter's elopement with a Black man was considered to have "a prejudice against the colored people." He was alleged to have said at a parents' meeting "that the people from the South, meaning the Slaves, could not learn anything anyhow."100 A decade later, when a Salt Spring trustee (\#29) sought to require the teacher to be ever-present with the children, the inferiority argument was turned in the other direction. "Our country districts are made up of a mixed population, \& with many of them their morals are very poor, if they have any at all," so that "for those children who have been reared in innocence it is nothing less than a cruel shame, as well as to their parents."101

\section{Consequences For Teachers}

Teachers were, and still are, the front line in the schools. Each of the teachers caught up in these thirty encounters with sexuality bore the consequences in one way or the other. In some cases they were clearly the instigators and deserved to be dismissed. With the South Cowichan teacher (\#1) charged with "taking indecent liberties" with a young mixed-race girl, the trustees "decided unanimously that the teacher should be suspended," whereupon he resigned his position. ${ }^{102}$ The music teacher said to have caused a "great scandal" at Cache Creek (\#7) was immediately discharged, as was the head teacher (\#5) held responsible for girls getting into the boys' dormitory. ${ }^{103}$ The male teacher accused of undue attention to "some of the large girls" at Langley Prairie (\#26) was asked by the trustees

99 L. Gold to John Jessup, SE, undated.

100 S[am] G. Lewis, teacher on Saltspring Island, to C.C. McKenzie, SE, Vesuvius Landing, 12 Feb. 1882.

101 T.W. Mouat, trustee, to S.D. Pope, SE, Vesuvius Bay, 13 Aug. 1895.

10213 March 1874 entry in John Jessup, "School Inspector's Diary 1872-77.”

103 Thomas Leduc, teacher at Cache Creek, to C.C. McKenzie, SE, Cache Creek, 26 Feb.1879. 
to resign and did so. ${ }^{104}$ On learning of the paternity affidavit against him, the teacher at Port Haney (\#23) admitted his guilt. ${ }^{105}$ The trustees voted unanimously that he "be summarily dismissed as Teacher of Hany [sic] School for Gross Misconduct," a decision made possible by the 1888 legislation. ${ }^{106}$ Acting as "the voice of the whole school district," they then requested the Superintendent of Education to have his certificate cancelled. ${ }^{107}$ Two weeks later, the superintendent agreed to do so "on account of gross misconduct."108

Other teachers were less willing to acquiesce to their departure, as with the Hope teacher (\#30) who justified his own failings by students' bad language. The Yale teacher (\#9) accused of letting "a halfbreed boy" act improperly toward children kept after hours took the offensive and "asked the children if the boy had ever been in the schoolroom when any of them had been kept in and they all immediately answered no! never!"109 The Mission man (\#25) who complained to the Superintendent of Education over pupils' inappropriate language reported that, when his wife talked to the teacher about it, he replied in an insulting manner. ${ }^{110}$

The teachers at Maple Bay and Vernon successfully resisted, even though accusations were levelled directly against them. The Maple Bay teacher (\#11) said to have beaten his wife to such an extent that, as one of the trustees put it, "she begs of us to send him away or he will kill her," survived boycott. ${ }^{111}$ Whatever the fate of the marriage, he was still teaching there the next year. Similarly, the Vernon teacher (\#19) accused of assaulting a female student "was very stubborn" and, a trustee reported, refused to resign on being requested to do so but vigorously proclaimed his innocence. ${ }^{112}$ In reference to the elevenyear-old who "told her mother I had been feeling her breasts!!" the teacher explained that she had been "kept after school for an imperfect recitation" and "when she came up to recite her lessons I took her on my knee... as I had times before." "No improvement

104 D. L. Stone, secretary of Belmont trustees, to S.D. Pope, SE, Langley Prairie, 9 April 1893.

105 Hector Ferguson to S.D. Pope, SE, Port Haney, 28 Aug. 1892.

106 H.H. Ansell, secretary of Haney trustees, to S.D. Pope, SE, Haney, 24 Aug. 1892.

107 Port Haney trustees to S.D. Pope, SE, Port Haney, 17 Aug. 1892.

108 Decree of 31 August 1892, Council of Public Instruction, “Decrees," p. 45, in BCA, GR 138, vol. 1.

109 A[delaide] Bailey, teacher at Yale, to C.C. McKenzie, SE, Yale, 31 March 1880.

110 James Tretheway to S.D. Pope, SE, Mission City, 13 June 1893.

111 William Beaumont, Maple Bay trustee, to C.C. McKenzie, SE, Maple Bay, 18 Feb. 1881.

112 E.J. Tronson, secretary of board of trustees, to S.D. Pope, SE, Spring Farm, Okanagan, 4 Feb. 1890. 
being apparent," he had repeatedly punished her with "a small gad, the smaller end not larger than a slate pencil (I can produce it)." Explaining why he was charged, "she having only a thin calico dress \& a chemise the gad left three or four red marks." "113 Like his Maple Bay counterpart, the teacher at Vernon kept his job.

Trustees did sometimes use their power to keep on a teacher they considered unjustly tainted. In a few cases nothing much ensued, as with the Hope woman teacher (\#8) linked by innuendo to a young "Half-breed boy"114 and the Langley teacher (\#28) who had a parent complain of their two young daughters' attempted rape. ${ }^{115}$ After the Mayne teacher (\#16) charged by a recent school-leaver with drawing female images denied the charges, he was exonerated, in part on the grounds that he "was a married man at the time."116 In the case of the Donald teacher (\#22) whose reliance on physical discipline was sexualized in the hopes of securing his dismissal, two of the three trustees voted at the end of a very contentious public meeting to continue to employ him. ${ }^{117}$

Several male teachers fell victim to a boycott. The Maple Bay teacher (\#15) withstood almost a month of boycott instigated by a religious zealot before submitting his resignation. Almost as an afterthought, he noted how "it is regrettable that dissension among the people works sadly against the welfare of the school." 118 The teacher caught in the impasse at Aldergrove (\#20) between two sets of parents over a six-year-old's "outrage" ended up out of a job when the school was closed for low attendance. ${ }^{119}$ At nearby Cheam (\#24), girls' reluctance to state publicly the charges they made to their parents did not break the boycott. The trustees similarly gave the teacher a month's notice on the grounds of falling numbers. Once the number on Salt Spring (\#13) fell below the legal minimum of ten, the two Black trustees voted to close the school. ${ }^{120}$ The teacher, informed that "the misunderstanding which has occurred between you and the parents of the children who have been attending school being of such a nature that it does not appear probable that any arrangement can be arrived at so as to secure a reasonable

113 R.S. Hanna to S.D. Pope, SE, Fairhaven, Washington, 31 Jan. 1890.

114 J[ane] E. Trenaman, teacher at Hope, to C.C. McKenzie, SE, Hope, 11 Dec. 1879.

115 Mrs. H.A. Oakes to S.D. Pope, SE, Langley, 24 July 1895.

116 Memo by D. Wilson, 16 April 1888.

117 Unsigned report to S.D. Pope, SE, Donald, 5 Sept.1892.

118 H.W. Graves to S.D. Pope, SE, Maple Bay, 31 Aug. 1886.

119 S.D. Pope, SE, to R. Shortreed, Victoria, 25 May 1893.

120 Henry Sampson to C.C. McKenzie, SE, Salt Spring Island, n.d.. 
attendance," ${ }^{\prime 21}$ thereupon wrote to the superintendent, who responded that the decision "is quite legal." 122

Where teachers were dismissed, no recourse whatsoever existed. The Superintendent of Education reminded the Yale woman teacher (\#9) who was at loggerheads with the physician trustee that just two of the three trustees held "the power of appointing and discharging you and they can do the latter without stating any reason." 123 Sure enough, they did so, and there was absolutely nothing she could do. ${ }^{124}$ The superintendent similarly reassured Cheam trustees (\#24) that, "under the provisions of the School Act, the Trustees have full authority in appointment and dismissal of teachers."125

The same outcome could result voluntarily, as with the besieged teacher at Maple Bay (\#15). The Stanley teacher (\#6) living in the house of the trustee whose wife went off to Victoria found her only alternative to ongoing innuendo was resignation. "I scarcely knew what to do, there was no place where I could board but public houses and I did not want to go there."126 Among others who left, apparently of their own volition, by the end of the school year were the female teacher at Hope (\#8) accused of social improprieties, the male teacher at Lakes (\#10) faced with a boycott after he got into a dispute with a local businessman, the female teacher at South Gabriola (\#17) who caught a student out in "a vile immoral act on the road home from school,"127 the female teacher at Aldergrove (\#20) where a girl was "outraged" on the way home, ${ }^{128}$ the male teacher at Mission (\#25) where girls were accused of indecent language, and the male teacher on Salt Spring (\#29) whose students were said to have used bad language during the noon hour.

Almost two-thirds (18/30) of the thirty teachers left their jobs by the end of the year in which the allegation occurred. They did so in three-quarters $(11 / 15)$ of the cases where the allegation was against them. The four exceptions were the male teacher (\#11) accused in Maple Bay of assaulting his wife, his counterpart in Donald (\#22) queried over an improper life style, the Vernon teacher (\#19) charged with assaulting a female student, and the Superintendent of Education

121 J.P. Booth, Secretary, to S. G. Lewis, 10 Feb. 1882.

122 C.C. McKenzie, SE, to S.G. Lewis, n.d..

123 C.C. McKenzie, SE, to Adelaide Bailey, Victoria, 31 March 1880.

124 A[delaide] Bailey, teacher at Yale, to C.C. McKenzie, SE, Yale, 15 Aug.1880.

125 S.D. Pope, SE, to H. Proctor, Victoria, 22 May 1893.

126 Josephine McDonald to John Jessup, SE, Quesnelle, 4 May 1878.

127 S. Ruston, teacher at South Gabriola, to S.D. Pope, SE, South Gabriola, 7 June 1888.

128 Arthur F. Goldsmith to S.D. Pope, SE, Aldergrove, 29 April 1893. 
against whom blackmail was attempted. Both women were among those who departed. Where the allegations were against students, almost half $(7 / 15)$ of the teachers also left, indicating how damaging could be even the tinge of sexuality. All of the women departed except the Granville female teacher twice involved in student accusations (\#2, \#3). Just over half (7/12) of the male and two-thirds (4/6) of the female teachers who quit or were forced out rebounded. They went on to other teaching jobs, sometimes after a year out. Of the seven who left the occupation altogether, five, all men, had allegations levied directly against them.

\section{Lessons from the Past}

Sex and sexuality have existed within schools so long as the institutions themselves. The contexts in which bodies engage in behaviour with a sexual edge may have changed, but the acts themselves resonate across time.

We know about these thirty allegations because they were communicated to the Superintendent of Education, his correspondence being the body of data whence they come. The state's reluctance to act, despite having ultimate authority, continues into the present day. Centralization of schooling has tended to focus on elements of education most easily controlled by virtue of being able to be measured and counted. We prefer to consider students and teachers to be rational beings whose bodies defer to their minds. Body behaviour is by its very nature not amenable to legislation, whose logical basis is at odds with the subtle shades of grey that colour most of our actions to do with sexuality and the body. The inability to accept sexual desire as part of the human condition put the onus in these thirty cases on localities. Very often it was parental action in the form of boycott which, directly or indirectly, precipitated a resolution. The end result sometimes had far less to do with the merits of the allegation than with excising the taint of sexuality from the school and, perhaps also, the locality. By virtue of being outsiders, teachers were expendable.

It is important to emphasize that both teachers and students sometimes woefully misbehaved. With some students, judicious handling of the situation likely prevented reoccurrence, but the situation with teachers was far more serious. The allegations represented acts of will with long-term implications for the organization of public schooling. The 1888 legislation making it possible to fire teachers for "gross misconduct" acknowledged their 
seriousness. Localities sometimes struggled to reconcile their assumptions about the teacher as a role model, so central to the rhetoric of public schooling, with accusations originating with small children. All sides lost out in these encounters with sexuality. Numerous children had their lives scarred in circumstances where no one, except possibly their parents, treated their situations as seriously as they might have done.

Males are more susceptible to allegations of improper body behaviour than females. Some scholars have argued that men are by nature "more aggressive and sexually impulsive." 129 What is clear is that men were, to some extent, the victims of their gender. Not only was sexual desire considered to be the prerogative of men, the greater power they exercised in society made them dangerous in circumstances where the situation appeared to be spinning out of control. Over the last three decades of the nineteenth century the proportion of men in the classroom declined from 60 to 40 per cent, whereas the proportion of encounters with sexuality occurring in schools employing male teachers rose from 50 per cent $(5 / 10)$ in the 1870 s to 80 per cent $(8 / 10)$ and then fully 90 per cent $(9 / 10)$ in the 1890s. Where the charges were against students, about two-thirds $(10 / 15)$ of the teachers were male. Apart from three incidents in the 1870 s, all of the fifteen allegations against teachers were levelled at men. In similar fashion, Bruce Curtis discovered for Ontario that, "despite the overwhelming numerical superiority of women in the teaching force (72 per cent by 1901), complaints of illicit sexual behaviour were far more frequently made against male teachers." 130

Although the thirty incidents are insufficient to draw generalizations, they do suggest that the feminization of teaching occurring across North America during these same years may have had to do not only with perceptions of women as maternal and with economic and structural factors, but also with issues of sexuality. As Bruce Curtis concludes for Ontario during these same years, "one reason for the feminization of the teaching force... may then also have been the perception of trustees and ratepayers that such teachers would not make unwelcome sexual advances to students, or engage them in other forms of illicit sexual comportment."131 An accusation, whatever its validity, may have tipped the balance, particularly in remote localities, toward hiring women teachers. Following events at

129 David T. Courtwright, Violent Land: Single Men and Social Disorder from the Frontier to the Inner City (Cambridge: Harvard University Press, 1996), 16.

130 Curtis, “'Illicit' Sexuality,” 87.

131 Ibid., 88. 
Hope (\#30), a trustee implored the superintendent: "Couldn't you send us a lady teacher who wouldn't be liable to drink." 132 It was, at least in part, innuendo that caused a Mayne trustee (\#16) to request the Superintendent of Education that "when you recommend us a School teacher...I think that a lady teacher would be preferable." The trustee's reasoning was straightforward. "We have girls grown pretty well up; and another thing the young male teachers are apt to play too much with the scholars and thereby in a measure loose [sic] the respect that is due to them as teachers." ${ }^{\prime 33}$ The number of incidents making it into the correspondence was not that high, although the whole total is impossible to determine. Precisely because there were so few, they may have been more likely to enter into the collective memory of communities.

It is extremely important that we do not view these thirty allegations as safely hidden away in the past. As Sue Middleton reminds us, we persist in teaching minds as opposed to minding bodies. ${ }^{134}$ We shy away from discussions of respectful body discipline, in and out of the schools. Children must be recognized as having bodies as well as minds in need of nourishment. However bemused we might be by the prudishness of the late-nineteenth century, these thirty encounters with sexuality echo into the present day.

132 W.A. Starret, Hope trustee, to S.D. Pope, SE, Hope, 29 April 1897.

133 W.T. Collinson, Plumper Pass trustee, to S.D. Pope, SE, Plumper Pass, 27 June 1888.

134 Middleton, Disciplining Sexuality. 